\title{
Tumor jinak kulit pada wajah
}

\author{
Ferra O. Mawu \\ Bagian Kulit dan Kelamin Fakultas Kedokteran Universitas Sam Ratulangi Manado \\ Email: fomawu@gmail.com
}

\begin{abstract}
Benign skin tumors are commonly found in every individual. There are various benign tumors occur on the skin surface including facial skin. The main problems of these tumors are cosmetic concerns and the possibility of malignancy. Benign skin tumors frequently found on the face are inter alia seborrheic keratoses, skin tag, syringoma, nevus pigmentosus, xanthelasma, sebaceous hyperplasia, and cyst. Several benign facial skin lesions can be diagnosed clinically as long as it is supported by careful examination with good anamnesis and proper lighting. Physicians as well as specialists must have the ability to categorize and diagnose accurately the growing lesions or tumors as benign, malignant, or undetermined in order to take further step for planning and providing treatment properly.
\end{abstract}

Keywords: seborrheic wart, skin tag, syringoma

\begin{abstract}
Abstrak: Hampir semua orang memiliki satu atau lebih tumor kulit yang pada umumnya adalah tumor jinak. Tumor jinak kulit dapat terjadi di seluruh permukaan kulit termasuk kulit wajah. Tumor kulit pada wajah umumnya menimbulkan masalah kosmetik dan kemungkinan pertumbuhan ke arah keganasan. Tumor jinak pada wajah yang sering ditemukan antara lain ialah keratosis seboroik, skin tag, siringoma, nevus pigmentosus, xantelasma, hiperplasia sebasea, dan kista. Secara klinik beberapa tumor jinak kulit pada wajah dapat langsung terdiagnosis, dengan syarat pemeriksaan dilakukan dengan teliti, mulai dari anamnesa sampai pemeriksaan fisik yang dilakukan di bawah penerangan yang baik. Dokter atau dokter ahli harus mampu mengategorikan tumor kulit sebagai tumor jinak/benigna, ganas/maligna, atau tidak jelas, sehingga kemungkinan penatalaksanaan dapat ditetapkan.
\end{abstract}

Kata kunci: keratosis seboroik, skin tag, siringoma

Tumor jinak kulit adalah pertumbuhan jaringan kulit yang bersifat kongenital atau akuisita sehigga terbentuk suatu massa, tanpa tendensi invasif dan metastasis, yang tidak menyebar ke bagian tubuh lain dan tidak merusak jaringan sekitarnya, sehingga tidak membahayakan., ${ }^{1,2}$

Terdapat sejumlah besar tumor jinak kulit yang dibagi dalam berbagai kelompok tetapi tidak ada satu sistem klasifikasi yang dipakai secara universal karena asal pertumbuhan dan gambaran klinik tumor jinak sangat bervariasi. ${ }^{3,4}$

Epidemiologi tumor jinak berbedabeda di setiap populasi karena terjadinya tumor dan perkembangannya dipengaruhi beberapa faktor terutama paparan sinar ultraviolet dan faktor familial. ${ }^{3,5}$

Hampir semua orang memiliki satu atau lebih tumor kulit yang pada umumnya adalah tumor jinak. Tumor jinak kulit dapat terjadi di seluruh permukaan kulit termasuk kulit wajah. Tumor kulit di wajah pada umumnya menimbulkan masalah kosmetik dan kemungkinan pertumbuhan ke arah keganasan. Tumor jinak di wajah yang sering ditemukan antara lain adalah keratosis seboroik, skin tag, siringoma, nevus pigmentosus, xantelasma, hiperplasia sebasea, kista, dan jenis tumor lainnya.

Secara klinik beberapa tumor jinak kulit di wajah dapat langsung terdiagnosis, dengan syarat pemeriksaan dilakukan dengan teliti, mulai dari anamnesa sampai 
pemeriksaan fisik yang di lakukan di bawah penerangan yang baik. Dokter atau dokter ahli harus mampu mengkategorikan tumor kulit sebagai tumor jinak/benigna, ganas/maligna, atau tidak jelas, sehingga kemungkinan penatalaksanaan dapat ditetapkan. $^{5,6}$

Penentuan diagnosis akurat untuk suatu tumor kulit adalah dengan pemeriksaan histopatologi terutama bila terdapat keragu-raguan dalam hal gambaran klinik dan membedakan kondisi jinak dari ganas. ${ }^{5,6}$

Penanganan tumor jinak kulit pada umumnya adalah dengan tindakan pembedahan. Tindakan pembedahan yang dapat dilakukan mencakup eksisi, insisi, kuretase, bedah listrik, bedah beku dan bedah laser. Semua tindakan ini akan memberikan hasil yang optimal bila dilakukan oleh dokter ahli atau dokter yang terlatih dengan menguasai pengetahuan tentang tumor jinak. ${ }^{7}$

Tinjauan pustaka berikut ini akan membahas beberapa tumor jinak kulit yaitu keratosis seboroik, skin tag, dan siringoma.

\section{KERATOSIS SEBOROIKA (KS)}

\section{Definisi}

Keratosis seboroika (KS), disebut juga seborrheic wart, senile wart, verruca seborrhoeica, atau basal cell papilloma, ${ }^{6,8}$ merupakan tumor jinak kulit yang berasal dari proliferasi epidermis dengan penumpukan keratin di atas permukaan kulit. ${ }^{4}$

\section{Epidemiologi}

Meskipun KS sangat sering ditemukan, hanya sedikit data statistik menyangkut prevalensi, jenis kelamin, ras, atau distribusi geografik. Beberapa studi telah melaporkan bahwa KS paling sering dijumpai pada populasi usia pertengahan dan meningkat di usia lanjut, terutama pada orang berkulit putih, prevalensi pria dan wanita sama, dan dapat juga lesi awal tumbuh di usia remaja. Satu studi di Inggris menemukan sebanyak 8,3\% pria dan $16,7 \%$ wanita usia kurang dari 40 tahun, memiliki sedikitnya satu lesi $\mathrm{KS}^{9}$ Pada populasi Australia ditemukan KS sebanyak 12\% kelompok usia 15-25 tahun, 79\% usia 2650 tahun, $100 \%$ usia 51-75 tahun, dan $100 \%$ usia > 75 tahun. ${ }^{10}$ Lesi KS kecil kemungkinan untuk menghilang spontan walaupun kebanyakan lesi akan terus muncul dan berkembang selama bertahuntahun. $^{3}$

\section{Etiologi dan patofisiologi}

Etiologi KS tidak diketahui pasti, diduga terdapat kecenderungan familial, paparan sinar matahari, dan infeksi. Individu dengan sejumlah besar lesi KS biasanya mempunyai riwayat keluarga dengan lesi yang sama. Tendensi familial ini diturunkan secara autosomal dominan. Epidermal growth factors beserta reseptornya diduga berperan dalam terbentuknya KS. Sejumlah mutasi gen reseptor tirosin kinase FGFR3 (fibroblast growth factor receptor 3) sering ditemukan pada beberapa tipe KS. Pada ikatan dimer FGFR3 terjadi induksi fosforilasi sehingga mengaktivasi mutasi pada FGFR3. Mutasi ini ditemukan sekitar $40 \%$ pada KS hiperkeratotik, $40 \%$ pada KS akantotik, dan $85 \%$ pada KS adenoid. ${ }^{11}$

Tingginya prevalensi KS pada kulit yang sering terpapar sinar matahari merupakan implikasi faktor sinar matahari sebagai etiologi. Hal ini masih kontroversi mengingat lesi KS dapat terjadi pada hampir semua permukaan tubuh termasuk area yang kurang atau tidak terpapar sinar matahari. Studi di Australia yang melihat distribusi 3067 lesi KS pada 100 pasien, menemukan distribusi lesi paling tinggi pada batang tubuh yaitu $54,7 \%$, tangan $15,2 \%$, wajah dan leher sebanyak $11,4 \%{ }^{10}$ Penelitian di Korea menemukan faktor independen yang berkontribusi dalam terjadinya $\mathrm{KS}$ adalah proses menua dan paparan sinar matahari. ${ }^{12}$ Ming et al, melakukan studi pada tikus dengan target supresor tumor yaitu phosphatase and tensin homologue on chromosom 10 (PTEN) di epidermisnya, menemukan bahwa UVA menyebabkan formasi tumor menyerupai KS dan karsinoma sel 
skuamosa manusia. ${ }^{13}$ Meskipun beberapa penelitian telah dilakukan, studi lanjut masih diperlukan untuk lebih memastikan hubungan sinar UV dan KS.

Infeksi virus dihubungkan dengan KS karena secara klinik mirip dengan kutil. Satu studi menemukan epidermodysplasia verruciformis-associated HPV DNA sebanyak 76\% dari 55 biopsi KS nongenital, temuan ini menunjukkan kemungkinan peran infeksi virus terhadap terjadinya KS. ${ }^{14}$ Studi lain oleh Gushi dkk, menyimpulkan hal yang sama setelah menganalisis 104 sampel KS non-genital pasien imunokompeten. Studi ini menemukan 87 sampel mengandung HPV-18, 81 sampel HPV-6, dan 73 sampel mengandung keduanya. ${ }^{15}$

KS memiliki variasi pigmentasi yang terjadi akibat sekresi melanocytestimulating cytokines. Sekresi sitokin ini dirangsang oleh proliferasi keratinost disekitarnya. Endothelin-1 memiliki dua efek stimuli yaitu sintesis DNA dan melanisasi, hal ini yang berperan pada terjadinya hiperpigmentasi KS. ${ }^{16}$

\section{Gambaran klinik}

KS dapat terjadi pada semua permukaan kulit dengan predileksi paling sering di wajah, leher, punggung, dan lengan. Lesi sering timbul pada area tidak berambut, biasanya dimulai dengan lesi datar, berwarna coklat muda sampai tua, berbatas tegas dengan permukaan licin seperti lilin atau hiperkeratotik. Diameter lesi bervariasi biasanya antara beberapa milimeter sampai $3 \mathrm{~cm}$. Lama kelamaan lesi akan menebal, dan memberi gambaran yang khas yaitu verukosa dan menempel (stuck on) pada permukaan kulit (Gambar 1). Lesi yang telah berkembang penuh tampak mengalami pigmentasi yang gelap dan tertutup oleh skuama berminyak.

Terdapat beberapa varian klinikopatologi KS yaitu: ${ }^{4,17-19}$

- Common seborrheic keratosis: secara klasik berupa papul verukosa yang menempel di kulit. Biasanya asimptomatik, sebagian terjadi gatal ringan.
- Reticulated seborrheic keratosis: merupakan papul atau plak berpigmen, biasanya diawali lentigo solaris (Gambar 2).

- Stucco keratoses: papul kecil, berdiameter sekitar 1-3 mm, keratotik, multipel, berwarna pucat yang timbul pada punggung tangan, tungkai bawah, dan punggung kaki (Gambar 3). Lesi mudah dilepaskan dari kulit dengan menggunakan kuku tanpa menyebabkan perdarahan.

- Dermatosis papulosa nigra: papul multipel berminyak warna coklat tua sampai hitam yang timbul di dahi, malar, dan leher, terjadi pada orang kulit hitam (Gambar 4).

- Leser-Trélat sign: erupsi mendadak lesi KS yang cepat berkembang disertai gatal. Keadaan ini dihubungkan dengan malignansi organ dalam, paling sering adalah adenokarsinoma perut. Mayoritas lesi berlokasi di punggung, diikuti dengan ekstremitas, wajah, dan abdomen. Patogenesis kelainan ini masih belum jelas, diduga berhubungan dengan sekresi growth factor oleh neoplasma yang menyebabkan hiper-plasia epitelial.
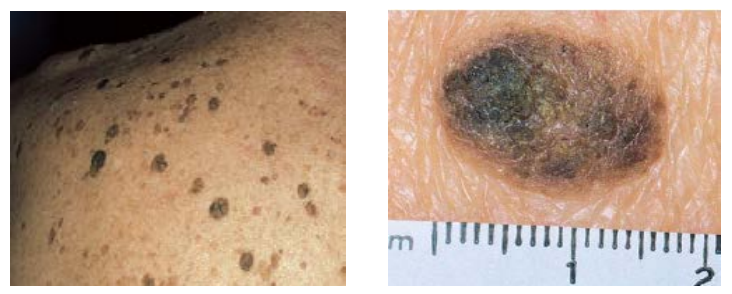

Gambar 1. Lesi KS dengan permukaan verukosa dengan pigmentasi gelap dan gambaran stuck on pada permukaan kulit. ${ }^{3,20}$
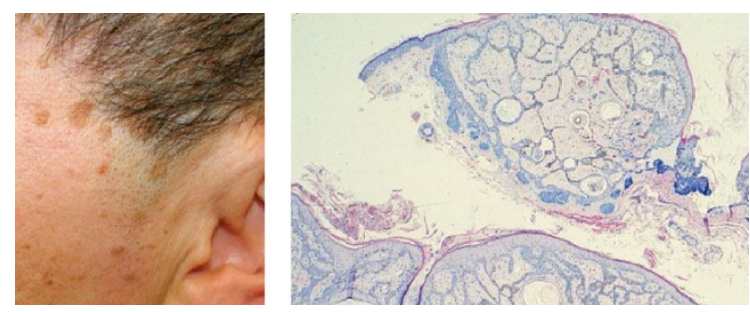

Gambar 2. Reticulated seborrheic keratose (klinik dan histopatologis). ${ }^{3}$ 


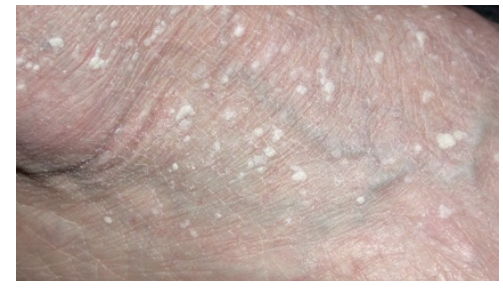

Gambar 3. Stucco keratosis ${ }^{21}$

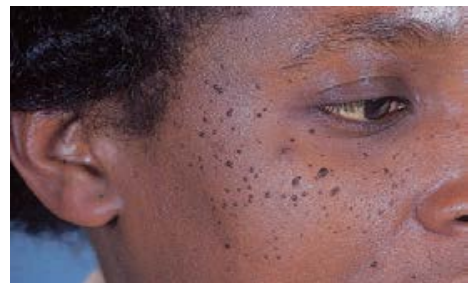

Gambar 4. Dermatosis papulosa nigra ${ }^{20}$

Varian klinik KS dapat dinilai dengan menggunakan dermoskopi. Dermoskopi atau yang dikenal dengan mikroskop epiluminesens memiliki akurasi diagnostik 5-30\% lebih tinggi dibandingkan visual inspeksi dan sangat membantu menilai adanya pertumbuhan gabungan tumor benigna dan maligna. ${ }^{22}$

\section{Diagnosis banding}

Hampir semua KS dapat teridentifikasi secara klinik meskipun terdapat berbagai kelainan lain yang memiliki gambaran klinik yang sama. Diagnosis banding KS mencakup veruka vulgaris, karsinoma sel basal berpigmen, nevus pigmentosus dan melanoma maligna.

\section{Penanganan}

Umumnya pasien tidak memerlukan terapi spesifik. Masalah klinis penyakit ini bersifat kosmetik yang mengganggu penampilan. Karena letaknya yang superfisial, KS mudah dihilangkan dengan kuretase, shaving, elektrodesikasi, eksisi, dermabrasi, bedah beku dengan nitrogen, dan laser. Eksisi lesi merupakan modalitas terapi yang sering menjadi pilihan. Sebaiknya selalu memastikan metode removal yang dipakai akan meminimalisasi risiko skar. ${ }^{3,19}$

Prognosis umumnya baik, jarang lesi
KS berubah menjadi ganas. Nevus displasia atau melanoma maligna kadang ditemukan pada individu dengan sejumlah besar lesi KS di batang tubuh. Pada keadaan dimana terdapat kecurigaan keganasan, biopsi eksisi merupakan tindakan yang tepat selain observasi dan evaluasi pasien secara teratur. ${ }^{6,19,23}$

\section{SKIN TAG}

\section{Definisi dan epidemiologi}

Skin tag, disebut juga soft wart, acrochordon, cutaneous papilloma, fibroma durum, fibroepithelial polyp, atau soft fibroma, merupakan tumor jinak kulit yang berasal dari jaringan fibrovaskuler epidermis dan dermis, sering menggantung, terutama pada area lipatan kulit. Banyak ditemukan pada usia pertengahan dan orang tua, umumya pada wanita. Pada populasi umum prevalensi mencapai $25-46 \%$ yang meningkat insidennya sejalan peningkatan usia. Sebanyak 59\% populasi memiliki skin tag sebelum usia 70 tahun.,6,17

\section{Etiologi dan patofisiologi}

Penyebab pasti kelainan ini belum diketahui. Teori sebelumnya menyebutkan berkurangnya elastisitas jaringan menyebabkan timbulnya lesi atrofik atau lesi yang melekat ke kulit. Variasi pedunkulasi atau tangkai yang terbentuk kemungkinan akibat luasnya area elastin yang hilang, namun pada studi jaringan elastin pada fibroepithelial polyps di tahun 1999 tidak ditemukan kelainan yang signifikan. ${ }^{24}$

Faktor predisposisi antara lain obesitas, penuaan, diabetes dan kehamilan. Iritasi akibat gesekan berlebihan diduga sebagi faktor kausal yang penting utnuk terjadinya skin tag, terutama pada obesitas. Pendapat lain juga menyebutkan bahwa skin tag merupakan efek dari proses kulit yang menua diperberat oleh sinar matahari. ${ }^{2,17}$ Studi oleh Akpinar dan Dervis mendapatkan bahwa kelompok acrochordon menunjukkan nilai yang lebih tinggi dibandingkan kelompok kontrol untuk indeks massa tubuh, kolesterol total, dan LDL. ${ }^{25}$ Penelitian cross-sectional pasien 
dewasa di suatu rumah sakit pendidikan menemukan hubungan yang signifikan antara resistensi insulin dengan skin tag multipel pada 98 pasien tanpa melihat faktor lainnya. ${ }^{26}$ Molluscum fibrosum gravidarum dan acrochordon yang identik dengan skin tag terjadi pada kehamilan dan biasanya mulai bulan ke-4 sampai bulan ke-6 yang menghilang setelah partus. Patofisiologinya tidak diketahui pasti, kemungkinan akibat adanya ketidakseimbangan hormonal dan tingginya epidermal growth factor selama kehamilan yang dapat merangsang pertumbuhan tumor. $^{27}$

Adanya keterlibatan infeksi HPV terhadap terjadinya skin tag sampai saat ini masih belum jelas karena beberapa studi memberikan hasil yang berbeda. ${ }^{28,29}$

\section{Gambaran klinik}

Skin tag sering ditemukan bersamaan dengan KS pada daerah leher dan intertriginosa (aksila, inframammae, lipat paha), dapat profus sampai ke wajah, punggung dan dada, dengan gambaran klinis berupa papul bulat/oval, teraba lunak, bertangkai dengan panjang bervariasi, ukuran massa $1 \mathrm{~mm}-1 \mathrm{~cm}$, warna mulai dari sewarna kulit sampai hiperpigmentasi.

Birt-Hogg-Dube (BHD) syndrome adalah suatu genodermatosis yang diturunkan secara autosomal dominan yang ditandai dengan trias tumor jinak kulit yaitu fibrofolliculoma, trichodiscoma, dan acrochordon yang tersebar di kepala, wajah dan tubuh bagian atas. Lesi biasanya muncul di usia 30 atau 40-an, meskipun dapat ditemukan juga pada usia yang lebih muda. Pasien dengan kelainan ini berisiko mengalami malignansi terutama renal dan kolon serta kolaps paru spontan akibat kista pulmonal. Gen abnormal untuk sindrom ini telah teridentifikasi dan diduga suatu tumor supresor namun demikian kelainan ini tidak selalu dialami mereka dengan gen BHD abnormal. ${ }^{30-32}$

\section{Diagnosis banding}

Skin tag sangat mudah didiagnosis secara klinik, jarang terjadi kesalahan diagnosis. Skin tag dapat seperti lesi KS yang kecil, bahkan sebagian memasukkan skin tag sebagai varian KS. Skin tag biasanya lebih kecil dibandingkan nevus melanositik atau lesi neurofibromatosis. Moluskum kontagiosum tidak bertangkai, sering pad anak-anak, terdapat central delle.
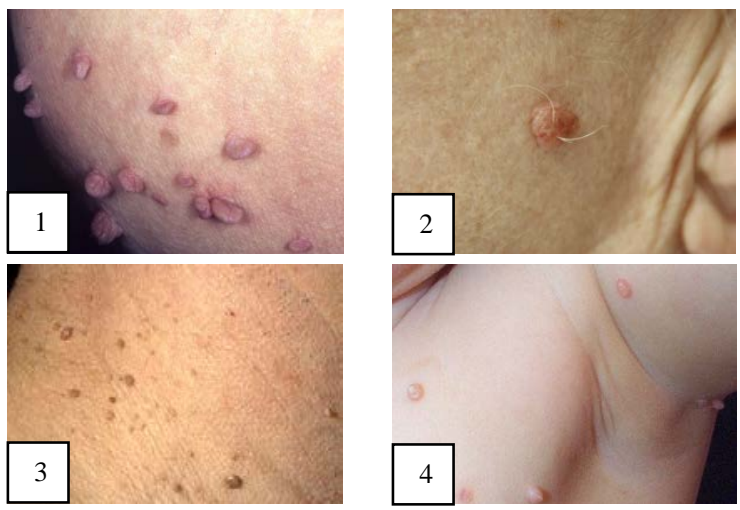

Gambar 5. Skin tag (A) dan beberapa lesi yang menyerupai skin tag, melanositik nevus (B), KS (C), moluskum kontagiosum(D) ${ }^{5}$

\section{Penanganan}

Skin tag bukan ancaman malignansi pada dewasa, terapi biasanya untuk alasan kosmetik atau karena iritasi. Terapi paling mudah dan tanpa anestesi ialah dengan scissor excision. Lesi kecil dapat diterapi dengan elektrodesikasi atau cryotherapy. Lesi berukuran $>2 \mathrm{~cm}$ harus dieksisi. Kadang-kadang dapat terjadi resolusi spontan, tetapi biasanya menetap dalam waktu lama. Evaluasi patologik tidak perlu dilakukan kecuali skin tag muncul di masa kanak-kanak, sebab biasanya merupakan inisial presentasi dari sindrom nevoid basal cell carcinoma. ${ }^{4,32}$ Selain itu analisis histopatologik perlu dilakukan terutama bila ada kecurigaan neoplasma pada suatu acrochordon. Pada tahun 2004, Schwartz et al. menemukan suatu karsinoma sel skuamosa di dalam lesi fibroepithelial polyp. $^{33}$

\section{SIRINGOMA \\ Definisi dan epidemiologi}

Siringoma atau hidradenomes eruptifs, syringocystadenoma, syringocystoma adalah tumor jinak adenoma 
duktus kelenjar ekrin intraepidermis yang biasanya multipel.

Siringoma sangat jarang ditemukan pada populasi umum; di Amerika terdapat pada sekitar $1 \%$ populasinya. Wanita lebih sering mengalami siringoma dibanding pria. Biasanya onset inisial di masa pubertas dengan lesi bertambah beberapa waktu kemudian. ${ }^{19,32}$

\section{Etiologi \& patofisiologi}

Siringoma biasanya sporadik atau terjadi spontan. Beberapa kasus terjadi dengan latar belakang familial yang diturunkan secara autosomal dominan. Meskipun belum ada studi insiden siringoma yang dihubungkan dengan ras tertentu, siringoma eruptif secara statistik lebih sering ditemukan pada orang AfroAmerika dan Asia. ${ }^{5,19}$

Siringoma secara umum dianggap sebagai neoplasma jinak yang berdiferensiasi sepanjang jalur ekrin. Sulit untuk membedakan antara duktus ekrin dan apokrin. Beberapa peneliti menyimpulkan bahwa pada kasus-kasus siringoma eruptif, terjadinya hiperplasia duktus ekrin lebih merupakan respon terhadap reaksi inflamasi. ${ }^{34}$ Teori inflamasi ini didukung adanya beberapa laporan siringoma pada alopesia sikatrisial, prurigo nodularis, dan setelah terapi radiasi. ${ }^{35}$

Siringoma diasosiasikan dengan beberapa sindroma. Sindroma yang paling sering ialah Down syndrome dengan lesi terbatas pada regio periorbital, namun ada juga laporan siringoma eruptif pada sindroma ini (Gambar 6). Hubungan siringoma dengan Down syndrome sampai sekarang masih belum jelas. ${ }^{36,37}$ Sindrom unik lainnya ialah Nicolau-Balus syndrome yaitu suatu sindrom yang terdiri dari siringoma eruptif tipe diseminata mikropapuler, kista milium, dan atrofoderma vermikulata. ${ }^{35}$ Sangat jarang, siringoma diasosiasikan dengan BrookeSpiegler syndrome, suatu penyakit autosomal dominan yang khas ditandai dengan multipel silindroma, trikoepitelioma, spiradenoma, dan siringoma. ${ }^{38}$

Beberapa literatur menyebutkan pengaruh hormon terhadap terjadinya siringoma. Hal ini dikonfirmasi dengan adanya peningkatan insiden siringoma pada wanita sebelum dan sekitar masa pubertas dengan keluhan pruritus setiap siklus menstruasi. Juga dilaporkan manifestasi siringoma vulva selama kehamilan. ${ }^{35}$ Pengaruh hormonal lainnya ialah adanya laporan clear-cell syringoma yang diasosiasikan dengan diabetes melitus. ${ }^{39}$

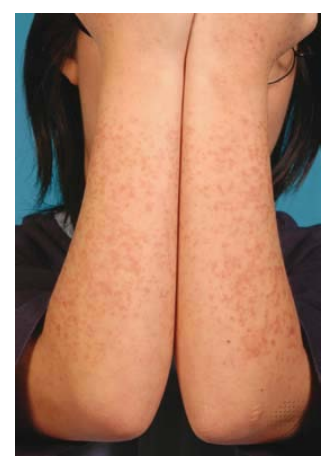

Gambar 6. Siringoma pada trisomy $21^{37}$

\section{Gambaran klinik}

Presentasi klinik siringoma yang bervariasi sudah sering dilaporkan. Pada tahun 1987 Friedman dan Butler membagi siringoma ke dalam empat varian klinik yaitu: ${ }^{35}$

1. Bentuk lokal

2. Bentuk diseminata (siringoma multipel dan eruptif)

3. Bentuk yang berhubungan dengan Down's syndrome

4. Bentuk familial

Siringoma biasanya asimtomatik, lesi berupa papul-papul datar lunak/padat lunak, diameter l-5 mm, paling sering $<3 \mathrm{~mm}$, permukaan membulat atau rata, dengan warna umumnya sewarna kulit atau sedikit kekuningan tapi dapat pula agak merah muda atau bahkan kecoklatan, yang tersebar di daerah kelopak mata, leher, serta dapat pula dalam bentuk generalisata. Bentuk generalisata atau siringoma eruptif jarang dilaporkan, lebih sering terjadi pada wanita usia remaja dan dewasa muda. ${ }^{4,35}$

Bentuk klinik tersering ialah bentuk periorbital, dan umumnya lesi awal timbul 
di area periorbital inferior/kelopak mata bagian bawah (Gambar 7). Bentuk yang jarang dilaporkan ialah milium-like syringoma, siringoma dengan lesi unilateral dan clear-cell syringoma. ${ }^{35}$

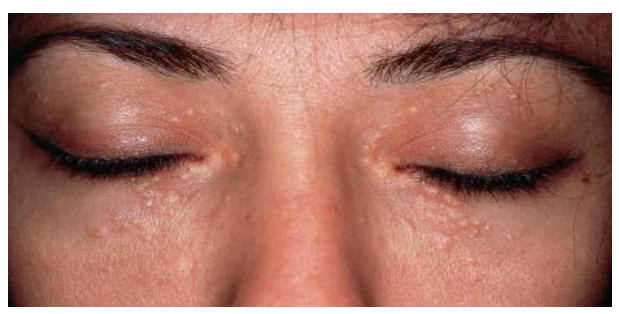

Gambar 7. Siringoma pada area periorbita ${ }^{19}$

\section{Diagnosis banding}

Diagnosis banding tersering ialah milia, diikuti trikoepitelioma, veruka plana, xanthoma eruptif, dan akne. Siringoma cenderung lebih kecil, kurang superfisial, tepi atas lesi lebih rata dan tersebar di pipi dan kelopak mata. Lesi pada kelopak sering menyerupai xantelasma namun berbeda warna. Eruptif siringoma di batang tubuh didiagnosis banding dengan granuloma anulare diseminata. Lesi granuloma anulare lebih eritematosa, lebih padat, berawal dari akral dan batang tubuh, papul sering bergabung membentuk plak. ${ }^{3,4}$

\section{Penanganan}

Pengobatan bertujuan destruksi tumor dengan skar minimal. Pilihan pengobatan antara lain dengan bedah eksisi, kuretase, krioterapi, chemical peeling, dermabrasi, elektrodesikasi dan terapi laser. Beberapa teknik pengobatan siringoma yang belakangan ini banyak dikembangkan antara lain elektrodesikasi menggunakan short burst high frequency low voltage intralesional dengan memakai elektroda jarum halus atau jarum epilasi, atau kombinasi laser CO2 vaporisasi dengan aplikasi asam trikloroasetat 50\% memberikan hasil yang cukup memuaskan, tanpa jaringan parut dan bebas lesi 6 bulan hingga 4 tahun. ${ }^{40,41,42}$

\section{SIMPULAN}

Hampir semua pertumbuhan pada kulit wajah tergolong keadaan jinak dan tidak membahayakan, namun membedakannya dengan kondisi keganasan kulit sangat penting. Biopsi kulit ialah langkah selanjutnya untuk suatu penegakkan diagnosis.

Terapi tumor jinak kulit di wajah paling sering melalui tindakan pembedahan, namun untuk kasus tertentu tidak memerlukan terapi atau diberikan terapi non-pembedahan. Tumor jinak kulit wajah yang tidak memberikan gejala dan yang menurut pasien tidak menggangu aktivitas atau kosmetik sering tidak memerlukan tindakan. Beberapa pertumbuhan jinak dapat menunjukkan suatu kondisi sistemik, termasuk kelainan hormonal namun biasanya hal ini tidak memengaruhi penanganan.

Tumor jinak kulit wajah terdiri dari berbagai variasi dalam hal definisi, asal pertumbuhan, gambaran histopatologis, dan bentuk. Pemahaman tentang tumor jinak kulit terutama yang sering ditemukan di klinik merupakan hal yang esensial untuk membantu membuat diagnosis pasti dan penentuan terapi yang berujung pada kepuasan pasien dan dokter.

\section{DAFTAR PUSTAKA}

1. National Cancer Institute. Handbook of: What you need to know about melanoma and other skin cancer. Rockville USA: NIH Publication, 2010; p. 5.

2. Benign skin tumor of the skin. Definition. Online access. Page last updated: 23 Maret 2013. Available from: http://www.nlm.nih.gov/medlineplus/enc y/imagepages.

3. Thomas VD, Snavely NR, Lee KK, Swanson NA. Benign epithelial tumors, hamartomas, and hyperplasias. In: Goldsmith LA, Katz SI, Gilchrest BA, Paller AS, Leffel DJ, Wolff K, editors. Fitzpatrick's Dermatology in General Medicine (8th ed). New York: McGraw Hill, 2012; p. 1319-36.

4. Quinn AG, Perkins W. Non-melanoma skin cancer and other epidermal skin tumours. In: Burns $\mathrm{T}$, Breathnach S, Cox N, Griffiths C, editors. Rook's Textbook of Dermatology (8th ed). Oxford: Blackwell Publishing Ltd., 2010; p. 52.1 - 48.

5. Henry GI, Grevious MA, Zaenglein AL. Benign Skin Lesions. Online access. Page 
last updated March 2013. Available from: http://emedicine.medscape.com/article

6. Pariser RJ. Benign Neoplasma of the Skin. Med Clin North Am. J., Nov 1998; 82(6): $1285-307$.

7. Lamb S. The management of benign skin lesions. NZ Fam. Phy. J., Oct 2006; 33(5): $328-31$.

8. Braun RP, Rabinovitz H, Oliviero M, Kopf AW, Saurat JH. Dermoscopic diagnosis of seborrheic keratosis. Clin Dermatol. May-Jun 2002; 20(3): 270 - 2

9. Memon AA, Tomenson JA, Bothwell J, Friedmann PS. Prevalence of solar damage and actinic keratosis in a Merseyside population. $\mathrm{Br} \mathrm{J}$ Dermatol. Jun 2000; 142(6): 1154 - 9.

10. Yeatman JM, Kilkenny M, Marks R. The prevalence of seborrhoeic keratoses in an Australian population: Does exposure to sunlight play a part in their frequency? $\mathrm{Br}$ J Dermatol 1997; 137: 411.

11. Hafner C, Hartmann A, Real FX, Hofstaedter F, Landthaler M, Vogt T. Spectrum of FGFR3 mutations in multiple intraindividual seborrheic keratoses. J Invest Dermatol. Aug 2007; 127(8): 1883 -5 .

12. Kwon OS, Hwang EJ, Bae JH, Park HE, Lee JC, Youn JI, et al. Seborrheic keratosis in the Korean males: causative role of sunlight. Photodermatol Photoimmunol Photomed. Apr 2003; 19(2): $73-80$.

13. Ming M, Shea CR, Feng L, Soltani K, He YY. UVA induces lesions resembling Seborrheic Keratoses in Mice with Keratinocyte-Specific PTEN downregulation. J Invest Dermatol 2011 July; 131(7): $1583-86$.

14. Li YH, Chen G, Dong XP, Chen HD. Detection of epidermodysplasia verruciformis-associated human papillomavirus DNA in nongenital seborrhoeic keratosis. Br J Dermatol. Nov 2004; 151(5): 1060 - 5.

15. Gushi A, Kanekura T, Kanzaki T, Eizuru Y. Detection and sequences of human papillomavirus DNA in nongenital seborrheic keratosis of immunopotent individuals. J Dermatol Sci. 2003 Apr; 31(2): $143-9$.

16. Manaka L, Kadono S, Kawashima $M$, Kobayashi T, Imokawa G. The mechanism of hyperpigmentation in seborrheic keratosis involves the high expression of endothelin-converting enzyme-1alpha and TNF-alpha, which stimulate secretion of endothelin $1 . \mathrm{Br} J$ Dermatol. 2001 Dec; 145(6): 895 - 903.

17. Luba MC, Bangs SA, Mohler AM, Stulberg DL. Common benign skin tumors. Am
Fam Phy. Feb 2003; 67(4): 729 - 38.

18. Ghazal PA, Korber A, Klode J, Dissemond J. Leser-Trélat sign and breast cancer. The lancet. May 2013; 381: 1653.

19. Barnhill RL, Rabinovitz H. Benign Melanocytic Neoplasms. In: Bolognia JL, Jorizzo JL, Rapini RP, eds. Dermatology. 3rd ed. Spain: Mosby elsevier, 2010. p. $1713-736$

20. Hunter JA, Savin JA, Dahl MV, editors. Skin tumors. In: Clinical Dermatology (3rd ed). Australia: Blackwell Publishing, 2002; p. 253-68.

21. Benign keratinocytic and adnexal lesions. Seborrheic keratoses. Online access. Page last updated July 2013. Available from: http://dermnetnz.org/doctors/lesions/kerat inocytic.html

22. Simionescu O, Popescu BO, Costache M, Spulber ES, Gherghiceanu M, Blum A. Apoptosis in seborrheic keratoses: an open door to dermoscopic score. J Cell Mol Med. 2012;16(6):1223-31.

23. Elgart GW. Seborrheic keratoses, solar lentigines, and lichenoid keratoses. Dermatoscopic features and correlation to histology and clinical signs. Dermatol Clin. 2001;19(2):347-57.

24. Adams BB, Mutasim DF. Elastic tissue in fibroepithelial polyps. Am J Dermatopathol. 1999;21(5):446-8.

25. Akpinar F, Dervis E. Association between acrochordons and the components of metabolic syndrome. Eur J Dermatol. 2012;22(1):106-10.

26. Tamega Ade A, Aranha AM, Guiotoku MM, Miot LD, Miot HA. Association between skin tags and insulin resistance. An Bras Dermatol. 2010;85(1):25-31.

27. Kar S, Krishnan A, Shivkumar PV. Pregnancy and skin. J Obstet Gynaecol India. 2012; 62(3):268-75

28. Dianzani C, Calvieri S, Pierangeli A, Imperi M, Bucci M, Degener AM. The detection of human papillomavirus DNA in skin tags. Br J Dermatol. 1998;138(4): 649-51.

29. Pezeshkpoor F, Jafarian AH, Ghazvini K, Yazdanpanah MJ, et al. An association of HPV low risk and high risk subtypes with Skin Tag. Ir J Basic Med Sci. 2012; 15(3):840-6.

30. Birt-Hogg-Dube syndrome. Online access. Page last updated June 2013. Available from: http://www.dermnetnz.org/lesions/birthogg-dube.html

31. Kawasaki H, Sawamura D, Nakazawa H, Hattori N, Goto M, Sato-Matsumura KC, et al. Detection of 1733insC mutations in an Asian family with BirtHogg-Dube syndrome. $\mathrm{Br} \mathrm{J}$ Dermatol. 
2005;152(1):142-5.

32. Arnold HL, Odom RB, James WD. Andrew's Disease of the Skin Clinical Dermatology (9th ed). Philadelphia: WB Saunders, 2008; p. 565-79.

33. Schwartz RA, Tarlow MM, Lambert WC. Keratoacanthoma-like squamous cell carcinoma within the fibroepithelial polyp. Dermatol Surg. 2004;30(2):34950.

34. Guitart J, Rosenbaum MM, Requena L. 'Eruptive syringoma': a misnomer for a reactive eccrine gland ductal proliferation? J Cutan Pathol. 2003; 30(3):202-5.

35. Muller CS, Tilgen W, Pfohler C. Clinicopathological diversity of syringomas. Dermato-Endocrinology. 2009;1(6):282-8.

36. Schepis C, Siragusa M, Palazzo R, Ragusa RM, Massi G, Fabrizi G. Palpebral syringomas and Down's syndrome. Dermatology. 1994;189(3):248-50.

37. Ong GC, Lim KS, Chian LY. Eruptive syringoma in a patient with trisomy 21 . Singapore Med J. 2010;51(2):e46-7.
38. Uede K, Yamamoto Y, Furukawa F. BrookeSpiegler syndrome associated with cylindroma, trichoepithelioma, spiradenoma, and syringoma. J Dermatol. 2004;31(1):32-8.

39. Jeon EK, Cho AY, Lee Y, Seo YJ, Park JK, Lee JH. Multiple yellow-brown papules on the neck and anterior trunk of a patient with diabetes mellitus. Clin Exp Dermatol. 2009; 34(5):643-4.

40. Huang LP, Zhang L, Wang XL, Lin BW. A technique for periorbital syringomas: intralesional radiofrequency ablation. Int J Ophtalmol. 2012;5(2):181-5.

41. Hong SK, Lee HJ, Cho SH, Sep JK, Lee D, Sung HS. Syringomas treated by Intralesional Needles without Epidermal Damage. Ann Dermatol. 2010;22(3): 367-9.

42. Frazier CC, Camacho AP, Cockerell CJ. The treatment of eruptive syringomas in an African American patient with a combination of trichloroacetic acid and CO2 laser destruction. Dermatol Surg. 2001;27(5):489-92. 